\title{
Characterisation and genesis of the chalcedony occurring within the Deccan lava flows of the LIT hill, Nagpur, India
}

\author{
Kirtikumar Randive $^{1, *}$, Sushma Chaudhary ${ }^{1}$, Sneha Dandekar ${ }^{1}$, Kavita Deshmukh ${ }^{2}$, \\ Dilip Peshre ${ }^{2}$, M L Dora ${ }^{3}$ and Boris Belyatski ${ }^{4}$ \\ ${ }^{1}$ Department of Geology, RTM Nagpur University, Nagpur 440 001, India. \\ ${ }^{2}$ Metallurgical and Materials Engineering Department, V.N.I.T., Nagpur, India. \\ ${ }^{3}$ Geological Survey of India, Central Region, Seminary Hills, Nagpur, India. \\ ${ }^{4}$ Center for Isotope Research, A.P. Karpinsky Geological Institute (VSEGEI), St. Petersburg, Russia. \\ *Corresponding author.e-mail: randive101@yahoo.co.in
}

MS received 29 October 2018; revised 1 April 2019; accepted 10 April 2019; published online 5 July 2019

The Deccan trap basaltic lava flows host a plethora of secondary minerals, notably zeolites, quartz and calcite. These minerals occupy the vesicles and cavities that are formed during the solidification of the lava flows. Much attention has been given to beautifully developed zeolites of the Deccan traps and wellcrystallised quartz varieties such as rosy quartz and amethyst. However, a group of minerals consisting of cryptocrystalline and amorphous silica did not receive much attention despite their consistent occurrence in all parts of the Deccan large igneous province. The freshly exposed samples of the chalcedonic silica occurring in the vesicular basalt at the Laxminarayan Institute of Technology (LIT) hill, Nagpur University Campus, were studied, one of which was studied in detail using X-ray diffraction analysis, differential thermal analysis, thermogravimetric analysis, Fourier transform infrared and scanning electron microscope-energy dispersive spectroscopy. The present study has demonstrated that the secondary silica occupying vesicles in the basaltic lava flows was length-fast chalcedony showing fibrous morphology overprinted by grainy morphology. It was concluded that the mother fluid was a hot $\left(\sim 100-300^{\circ} \mathrm{C}\right)$ aqueous solution, which was acidic in nature and high in sulphur, probably derived from the host Deccan trap basaltic magma itself.

Keywords. Chalcedony; Deccan traps; basalt; secondary silica; amygdules.

\section{Introduction}

Amygdules (also known as amygdales) are gas cavities, or vesicles, in igneous rocks (usually volcanic or shallow intrusive) that are filled, or partially filled, with secondary minerals (Rakovan 2005). These minerals may have a late-stage magmatic origin or, more commonly, may form from post-magmatic aqueous solutions (Chemtomb and Rossman 2014). Common minerals in amygdules include calcite, quartz, chalcedony, chlorite and zeolites. The Deccan trap basalts are bestowed with a rich bounty of secondary minerals (e.g., Ottens 2003).

These deposits are formed from hydrothermal solutions that permeated basaltic lava flows and deposited copper-rich and other minerals by openspace filling (i.e., fractures and vesicles) and replacement. Vesicles are created by the expansion of gas bubbles or steam within molten lava. They 
are, therefore, usually rounded, elongated or almond-shaped. Vesicles and hence amygdules are generally more pronounced in basalts than in other volcanic rock types. This is partly because of the lower viscosity of basaltic lavas, which allows gas bubbles to readily expand before the lava solidifies. Vesicles are typically an inch or two in maximum dimension; however, they can be much larger. The larger ones are commonly known as pockets or vugs and are less likely to become completely filled by secondary minerals. If mineralised, they usually exhibit varying degrees of lining. The spectacular museum specimens of zeolites from the Deccan traps in India (Ottens 2003) are found mostly as amygdules or pocket linings. In some lava, rising gas bubbles may stretch out to form tubular vesicles. Mineralisation of these vesicles forms tube or pipe amygdules. Large tubular gas pockets (often many feet long) lined with amethyst and other accessory minerals, colloquially known as "cathedrals', are common in the basalts of Rio Grande do Sul, Brazil (Rakovan 2005). The term 'amygdule' is derived from the Greek word for 'almond'. There are some ambiguities in the semantics given above. Specifically, the dividing line between an amygdule and a mineralised pocket, and the degree of vesicle infilling necessary to be called an amygdule, is not precisely defined - although, vesicles and hence amygdules are usually less than 2 inches in size.

The Deccan large igneous province (LIP) is known for the occurrence of secondary minerals, such as zeolites, phyllosilicates, hydrated sulphates, carbonates, tungstates-molybdates, and even native elements like copper in cavities of varying shapes and sizes (Sukheswala and Poldervaart 1958; Sukheswala et al. 1974; Avasia and Gangopadhya 1984; Jeffery et al. 1988; Apte and Phadke 1996; Ottens 2003). Their presence is particularly conspicuous in 'pahoehoe' (i.e., compound) type lavas than 'aa' (i.e., simple) type lavas (Phadke and Bapat 1984). Zeolites (Apte and Phadke 1996 and references therein) and other aesthetically important minerals such as amethyst and calcite (Patil et al. 1981; Ottens 2003) were the subject of most of the previous studies on the secondary minerals of the Deccan traps. Although there are some passing references to the occurrence of cryptocrystalline and amorphous silica (e.g., Parthasarathy 2006), the hydrous (cryptocrystalline and amorphous) silica did not receive any significant attention despite their perpetual occurrence all over the mineralised areas.
The cryptocrystalline and amorphous silica, which commonly occur in the form of chalcedony, opal, wood-opal, onyx and other forms are omnipresent within the Deccan traps basaltic terrain. It is known that natural chalcedony forms under near surface conditions at low temperatures. These conditions are restricted to sedimentary and lowtemperature hydrothermal environments. The widespread association of chalcedony with opal and similar material and the conversion of opal to chalcedony are among the most-studied phenomena (Barth 1952; Williams et al. 1954; White 1955; Pettijohn 1957; Pittman 1959). Chalcedony has certain distinguishing properties such as low, variable refractive indices and fibrous appearance or undulose extinction. In addition, it is commonly brown in transmitted light, biaxial, chemically more reactive than quartz, and shows suppression of the low-high transition of quartz as commented on by Pelto (1956).

A variety of silicate minerals are known to occur as secondary cavity-filling deposits, especially in the volcanic basaltic terrains (Chemtomb and Rossman 2014). The Deccan traps basaltic lava flows almost invariably contain amygdales filled with crystalline and cryptocrystalline silica along with other minerals, especially zeolites (Sukheswala et al. 1974) and calcite (Ottens 2003). The crystalline minerals within the Deccan traps received much attention due to their aesthetic value and usefulness as precious/semi-precious stones. The cryptocrystalline silica, on the other hand, remain neglected notwithstanding their consistent and profuse occurrence throughout the Deccan LIP. However, recent researches have demonstrated their utility as the indicator of the chemical weathering of basaltic rocks and the palaeoenvironments (Chemtomb and Rossman 2014). Moreover, they find an exclusive importance in the study of the composition of the Martian surface (e.g., Kraft et al. 2003; Skok et al. 2010).

It is in this view that the present research work has been undertaken. In this study, the characterisation of amorphous silica occurring within Deccan trap basaltic lava flows of the Nagpur city and surrounding areas has been attempted. However, major emphasis has been placed on the freshly exposed samples from the dug well cuttings towards the northern foothill side of the Laxminarayan Institute of Technology (LIT) hill, LIT Campus, RTM Nagpur University. 


\section{Geology of the area}

Nagpur city $\left(21^{\circ} 09^{\prime} \mathrm{N} ; 79^{\circ} 07 \mathrm{E}\right)$, covering an area of about $100 \mathrm{~km}^{2}$, is situated at an altitude of over $290 \mathrm{~m}$ above the mean sea level. However, there is a general increase in ground elevation of about $350 \mathrm{~m}$ towards the western part of the city. Geomorphologically, the area is occupied by denudational hills, dissected pediments and pediplains (Gwalani and Dalal 1988; Subramanyanan et al. 1996).

The geology of Nagpur city has been studied in detail by Pande et al. (1969), Deshpande (1998) and Subramanyanan et al. (1996), and, more recently, the geological information was compiled by GSI (2000) on a regional scale. The following discussion is based mostly on the above references; a summary of the geology of Nagpur city is given in table 1 . The geological formations observed within Nagpur city (figure 1) include Precambrian crystalline metamorphic rocks, Permo-Carboniferous Lower Gondwana sediments, Upper Cretaceous Lameta sediments and Cretaceous-Palaeogene Deccan trap basaltic lava flows separated by intertrappean beds along with recent alluvium of the Nag and Peoli rivers. A detailed description of these rock formations is given below.

\subsection{Precambrian metamorphic rocks}

The Precambrian crystalline metamorphic rocks are represented by ortho-gneisses, streaky gneisses, amphibolites, marbles and pegmatites of the Sausar group. They are exposed between the
Mahadula and Suradevi, and Khaperkheda and Koradi. Metamorphics are also exposed near Bardi, Itwari, Indora, Pardi and Kalamna (figure 1); however, due to the thick population density, none of the outcrops are preserved. These formations are only exposed during excavation for dug well or drill holes. The Precambrian rocks lie concealed below the younger formations, and their direct contacts are occasionally seen with Gondwana sediments or Lameta formations, but rarely with the Deccan traps.

\subsection{Gondwana supergroup}

The rocks of the Lower Gondwana formations comprising Talchir, Barakar and Kamthi formations are exposed. Their dips commonly vary between $15^{\circ}$ and $20^{\circ}$ due SW to SSW. Greencoloured Talchir shales and basal conglomerates (tillites of glacial origin) are exposed towards the eastern side of the Koradi temple near a railway track adjacent of the Suradevi hills, as well in a stream section towards the north of Nagpur. Although no surface exposures of the Barakar formation are available, they are often encountered in the dug well and nala cutting sections below Kamthi sandstones. However, Barakar sandstones lie beneath the alluvium of the Kanhan river. Kamthi formation comprises ferruginous laminated sandstones, interbedded with reddish, white and buff coloured laminated shales. Their exposures are available near Jaripatka, Bokhara, Nara and Kalamna (figure 1). These sediments are found in direct contact with the Precambrian metamorphic

Table 1. Geological units occurring in Nagpur city (modified after Subramanyanan et al. 1996).

\begin{tabular}{|c|c|c|c|}
\hline $\begin{array}{l}\text { Geological time } \\
\text { unit }\end{array}$ & $\begin{array}{l}\text { Lithostratigraphic } \\
\text { unit }\end{array}$ & $\begin{array}{l}\text { Approx. max. } \\
\text { thickness } \\
\quad(\text { in } \mathrm{m})\end{array}$ & Description \\
\hline Recent to Quaternary & Alluvium and soil & 10 & Predominantly gravel, sand, silt and clay \\
\hline $\begin{array}{l}\text { Lower Eocene to } \\
\text { Upper Cretaceous }\end{array}$ & $\begin{array}{l}\text { Deccan traps and the } \\
\text { intertrappean bed }\end{array}$ & 48 & $\begin{array}{l}\text { Two basaltic lava flows separated by intertrappean } \\
\text { beds; compact to vesicular, amygdaloidal, } \\
\text { at places highly weathered and jointed basalts } \\
\text { Green earth, calcareous and fossiliferous clayey } \\
\text { and marly sediments }\end{array}$ \\
\hline Upper Cretaceous & Lameta formation & 15 & $\begin{array}{l}\text { Sandstones, earthy, red and white, silicified } \\
\text { limestones }\end{array}$ \\
\hline Upper Permian & Kamthi formation & 168 & $\begin{array}{l}\text { Sandstones, shales and ferrugineous (ochre, } \\
\text { reddish, brownish coloured) sandstones }\end{array}$ \\
\hline Lower Permian & Barakar formation & 140 & Sandstones, shales and carbonaceous shales \\
\hline Upper Carboniferous & Talchir formation & $>20$ & Green shales, bounder beds (tillites) \\
\hline Archaean & Sausar group & - & $\begin{array}{l}\text { Mica-schists, quartzites, marbles, streaky- and } \\
\text { ortho-gneisses }\end{array}$ \\
\hline
\end{tabular}




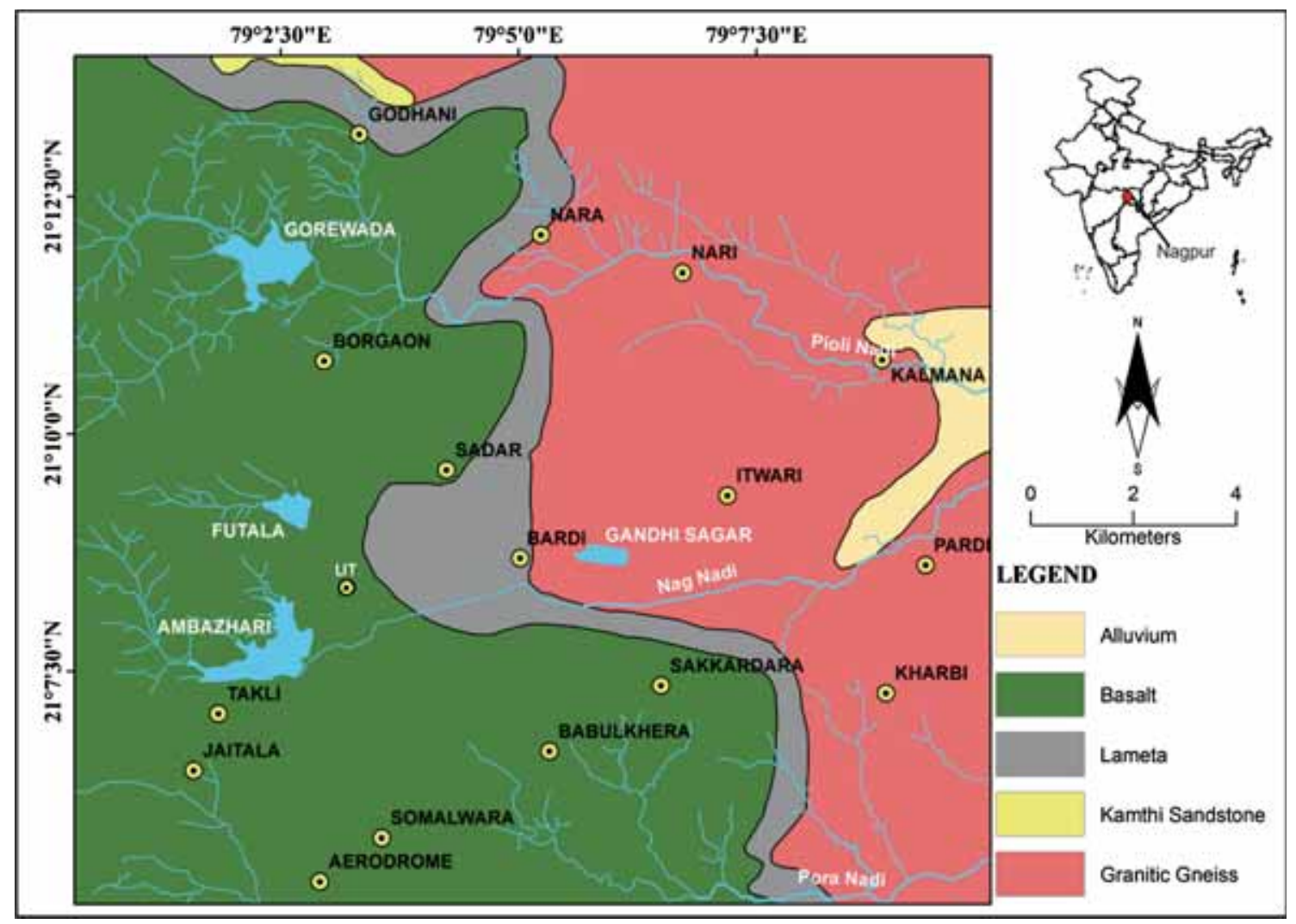

Figure 1. Geological map of Nagpur city and surrounding areas (modified after Pande et al. 1969; Gwalani and Dalal 1988; Subramanyanan et al. 1996).

rocks belonging to the Sausar group; although the contact is often faulted. Typical lower Gondwana plant fossils are found at these localities, especially Silewada $\left(21^{\circ} 12^{\prime} 22^{\prime \prime} \mathrm{N} ; 79^{\circ} 07^{\prime} 30^{\prime \prime} \mathrm{E}\right)$ and Bokhara $\left(21^{\circ} 15^{\prime} 58^{\prime \prime} \mathrm{N} ; 79^{\circ} 08^{\prime} 82^{\prime \prime} \mathrm{E}\right)$.

\subsection{Lameta formation (infratrappean)}

Lameta formation comprises white to off-white limestones with thin bands of sandstones and clays. A good population of fossils including vertebrate fossils and remains of dinosaurs are known to occur in the Lameta formation elsewhere (e.g., Mohabey and Udhoji 1996), although no records of their availability within Nagpur city area are available. The rocks belonging to the Lameta formation were seen in most dug wells in Dharampeth, Itwari and Sadar areas. They were also exposed in excavations made for laying pipelines and building foundations in many areas including Sri Mohini Complex, Sadar and Road Transport Office (RTO), Civil Lines. At these places, Lametas were buried under the soil cover and the overlying orthogneisses (Subramanyanan et al. 1996). The Lameta beds have been affected by a series E-W trending faults post the Deccan trap age (Pande et al. 1969).

\subsection{Deccan traps and intertrappean beds}

More than half of the city area, especially the western and the southern parts, is covered by the Deccan traps basaltic lava flows. A centrally situated step-like linear belt comprising the Lameta formation (figure 1) marks the boundary between older rocks and younger lava flows. The Deccan traps comprise a series of basaltic lava flows with each flow having a massive unit at the bottom and a vesicular unit at the top of the flow. Individual flows are separated by the sedimentary (clay or shale) parting of intertrappean beds. The basaltic lava flows are usually dark grey, compact, finegrained with clinker surfaces, irregular vesicles and fragmentary tops, resembling 'aa' type flow surfaces. They are well jointed and weather into angular to sub-rounded blocks. At some places, such as the LIT hill, prismatic columnar joints are exposed (figure $2 \mathrm{a}$ ). 

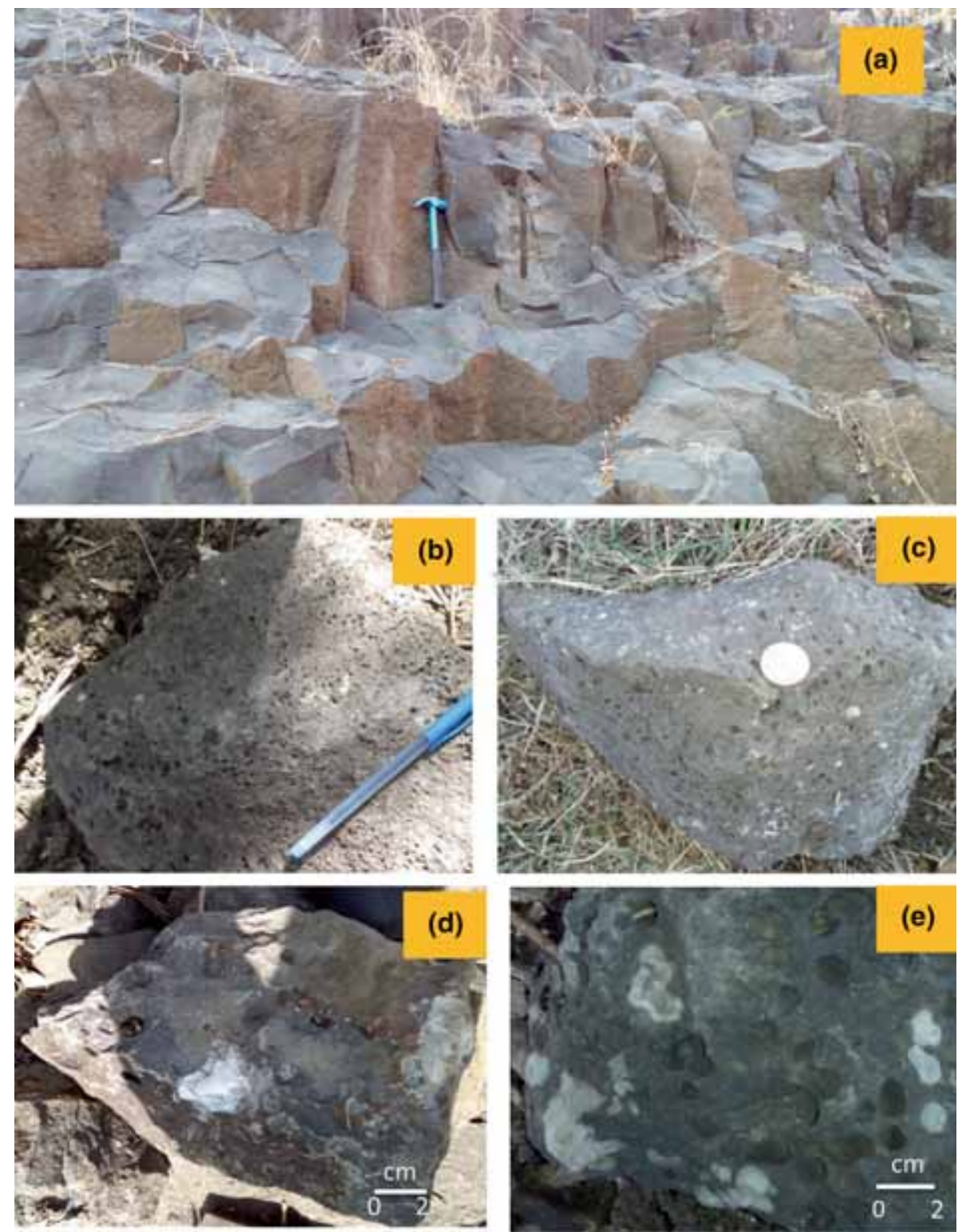

Figure 2. (a) Section of LIT hill exposing lower basaltic lava flow. Prominent columnar jointing pattern is seen. (b) Highly vesicular portion of the lava, most of the cavities are unfilled. Note that many of the cavities are irregular, elliptical and elongated. (c) An amygdaloidal portion of the lava. Here most of the cavities are filled with secondary silica, such spherical-, pear- and almond-shaped, pea-sized silica nodules get detached from the main rock and profusely occur in the overlying soil/ detritus. (d) Irregular cavities with silica infilling is seen. Also, note small veins indicating pathways for the flow of silica-rich solutions. (e) Typical pattern of cavity filling within the Deccan traps basaltic lava flows.

\subsection{Intertrappean beds}

The intertrappean beds of Nagpur are well studied, especially for their fossils. It is the type locality for the fresh water mollusks, notably, Physa principia (Hislop and Hunter 1855). The intertrappean sediments are exposed near Takli, Telankhedi, Ambazari, Ramnagar, Ramdeobaba hill and Dabha. However, recently exposed sections at Dhapewada and Mahurzari just at the fringe of Nagpur city are spectacular still today.

\section{Sampling and analysis}

To address the several traverses of the study, several traverses were made within the city limits and adjoining areas, but freshly exposed, sizable and un-weathered samples were difficult to obtain. However, a recently dug well in the premises of LIT $\left(21^{\circ} 08^{\prime} 44^{\prime \prime} \mathrm{N} ; 79^{\circ} 02^{\prime} 55^{\prime \prime} \mathrm{E}\right)$, RTM Nagpur University Campus, provided fresh samples of secondary silica (figure $2 \mathrm{~b}-\mathrm{e})$. The samples $(n=3)$ were carefully separated and cut to form thin and polished 
sections. Another chunk of the samples were finely powered and sieved, an ASTM of 200 mesh size. Among the samples selected, one of the samples was used for analyses using different techniques as mentioned below.

The X-ray diffraction (XRD) analysis of chalcedony was performed on a Panalytical X'Pert Pro (model-PW 3040/60) diffractometer with CuK $\alpha$ radiation $(\lambda=1.54 \AA)$ generated at a voltage of $40 \mathrm{kV}$ and a current of $40 \mathrm{~mA}$. Scanning was done in the $2 \theta$ angle of $5-80^{\circ}$ with a scan step size and time per step of $0.01^{\circ}$ and $15 \mathrm{~s}$, respectively. The morphological changes were investigated using a scanning electron microscope (SEM-JEOL 6830A). Prior to the study of surface morphology, the material was coated with a thin platinum coat using auto sputter (JOEL-JFC 1600 auto fine coater) to help the material conduct to obtain the images. Fourier transform infrared (FTIR) spectra of the samples were recorded using a Perkin Elmer Spectrum One FTIR. Potassium bromide (KBr) was used for collecting the background and a total of 20 scans were taken. The thermogravimetric differential thermal analysis (TGDTA) graph was generated using a thermogravimetric differential thermal analyser (Perkin Elmer Diamond TG/ DTA), and the sample was heated from room temperature to $1000^{\circ} \mathrm{C}$ at the rate of $10^{\circ} \mathrm{C} / \mathrm{min}$. Argon gas was perched for maintaining the inert atmosphere so as to avoid oxidation of the sample.

\section{Results}

\subsection{SEM analysis}

The SEM images indicate dominantly fibrous morphology at lower magnifications (typically less than $3500 \times$; figure $3 \mathrm{a}-\mathrm{c}$ ) and grainy morphology (on the surfaces) at very high magnification (more than $4000 \times$, more prominently at $8000 \times$; figure $3 \mathrm{~d}-\mathrm{f}$ ). Similarly, the XRD pattern coupled with high-magnification imaging by SEM indicates the presence of length-fast chalcedony in which crystallites are stacked perpendicular to the $c$-axis with the fibres twisted around the elongation axis and also indicating the overlapping of grainy over fibrous morphology.

\subsection{XRD analysis}

The results of the X-ray diffractometric study and the diffractogram is presented in figure 4 . The peak intensities corresponding to $2 \theta$ angles are located at $20.76^{\circ}, 26.57^{\circ}, 36.51^{\circ}, 39.41^{\circ}, 42.35^{\circ}, 50.05^{\circ}$, $59.86^{\circ}$ and $68.05^{\circ}$. The grain size was estimated using the Debye-Scherrer formula

$$
D=\frac{0.9 \lambda}{B \cos \theta},
$$

where $D$ is the mean size of the ordered (crystalline) domains, which may be smaller or equal to the grain size, $\lambda$ is $1.54 \AA$ for the wavelength of $\mathrm{CuK} \alpha$ radiation, $B$ is the full-width at halfmaximum and $\theta$ is the Bragg's angle.

Substituting values in the above formula, an overall size of the particles of crystal was calculated to be $\sim 22.61 \mathrm{~nm}$. It is clear from figure 4 that in the $2 \theta$ range from $20^{\circ}$ to $70^{\circ}$ there are at least six conspicuous peaks which can be indexed only on the hexagonal cells of chalcedony. In length-fast chalcedony, the grains appear to be stacked perpendicular to the $c$-axis, and along the $a$-axis, the virtual fibre axis is either (1120) or (1010) (Braitsch 1957). The preferred growth direction seems to be along (1010) in the sample, hence the sample is a length-fast chalcedony.

\subsection{DTA and TGA analyses}

DTA and TGA analyses and heat flow (DTA) and weight loss curves (TGA) are shown in figure 4 . The results of these studies are discussed below.

\subsubsection{Differential thermal analysis}

An initial endothermic peak is observed at $41.113^{\circ} \mathrm{C}$ at which the heat flow through the sample was about $-3.082 \mathrm{~mW}$. With the increasing temperature, there is a continuous rise in heat flow until it reaches a peak temperature of $206.113^{\circ} \mathrm{C}$ and the corresponding heat flow of $0.829 \mathrm{~mW}$. Further increase in temperature does not show much change with only a minor decrease in heat flow until it reaches $606.113^{\circ} \mathrm{C}$, where a major inflection of $0.852 \mathrm{~mW}$ is observed. Based on this curve (figure 5), two major inflection points were theoretically calculated. The first one corresponds to an endotherm of $\sim 173.85^{\circ} \mathrm{C}$ and the second one corresponds to that of $603.92^{\circ} \mathrm{C}$. These temperatures indicate that the mineral is broadly endothermic in character; the sharp endothermic peak at $603.92^{\circ} \mathrm{C}$ probably corresponds to dehydroxylation reactions. 

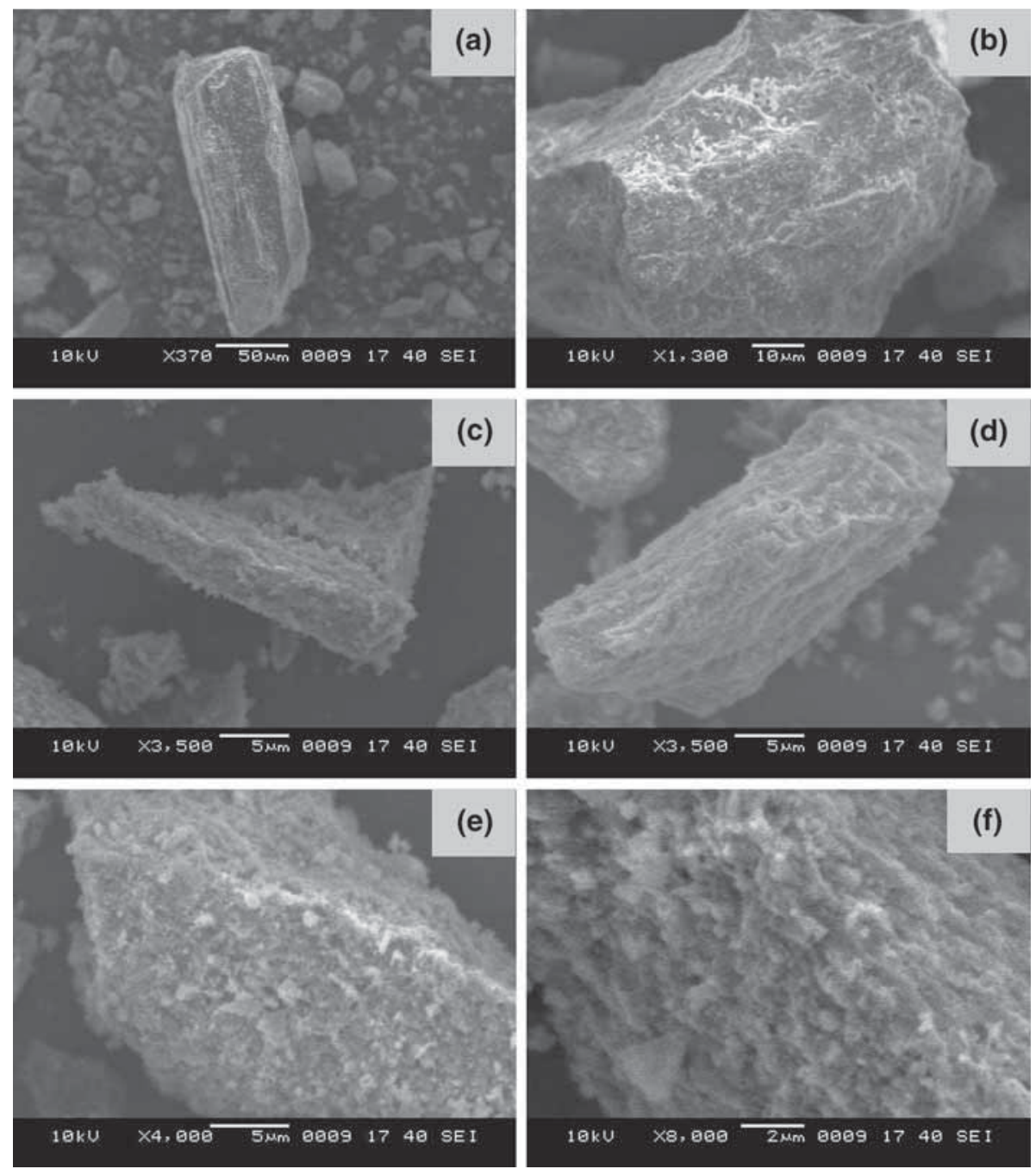

Figure 3. SEM images showing various morphological and textural features: (a) fibrous and bladed morphologies of chalcedony (magnification: $370 \times$ ). (b) A closer view of the surface shows somewhat coalesced fibres, the alignment of which is overshadowed by chonchoidal to subchonchoidal fractures formed due to the powdering of mineral (magnification: $1300 \times)$. $(\mathbf{c})$ bladed chalcedony overprinted with grainy morphology (magnification: 3500×). (d) Another crystal showing fibrous and bladed morphology, with little coalesced fibres (magnification: 3500×). (e) A crystal showing dominantly grainy morphology at higher magnification (magnification: $4000 \times$ ). (f) Highly magnified view of the same crystal demonstrating grainy morphology with directional fabric developed. Such a feature indicates that both fibrous and grainy morphologies are simultaneously present in the mineral under study (magnification: 8000×).

\subsubsection{Thermogravimetric analysis}

The TGA curve is much more complex and undulating compared to known samples (Parali et al. 2015). Here four major events of mass losses corresponding to temperatures of $\sim 37^{\circ} \mathrm{C}, \sim 190^{\circ} \mathrm{C}$, $\sim 580^{\circ} \mathrm{C}$ and $\sim 850^{\circ} \mathrm{C}$ were observed. The weightloss at the starting temperature is due to the loss of absorbed moisture by the sample. The second weight-loss $\left(\sim 190^{\circ} \mathrm{C}\right)$ may correspond to the loss of structural water. The third and fourth events of weight-loss are rather continuous, but prominently observed due to the drastic change in the slope on the curve (figure 5) between $\sim 580^{\circ}$ and $\sim 760^{\circ}$, and $\sim 850^{\circ}$ and above. The last two weight-losses might correspond to the dehydration of the silanol $(\mathrm{SiOH})$ group water from chalcedony (Hatipoglu et al. 2010).

\subsection{FTIR analysis}

The FTIR spectrograph of the sample shown in figure 6 was collected in the range of 450$4000 \mathrm{~cm}^{-1}$, as it was taken to confirm the presence of the functional group of the sample. The intense peak at wavelength $1105 \mathrm{~cm}^{-1}$ is estimated to match with the characteristics peak of the $\mathrm{Si}-\mathrm{O}$ 


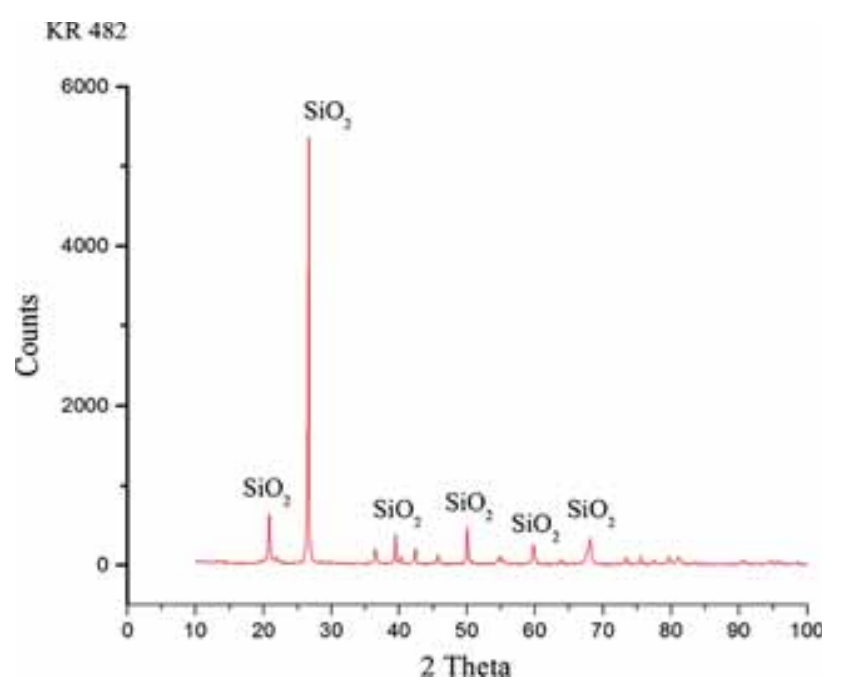

Figure 4. XRD pattern for the chalcedony sample analysed during this study (inset).

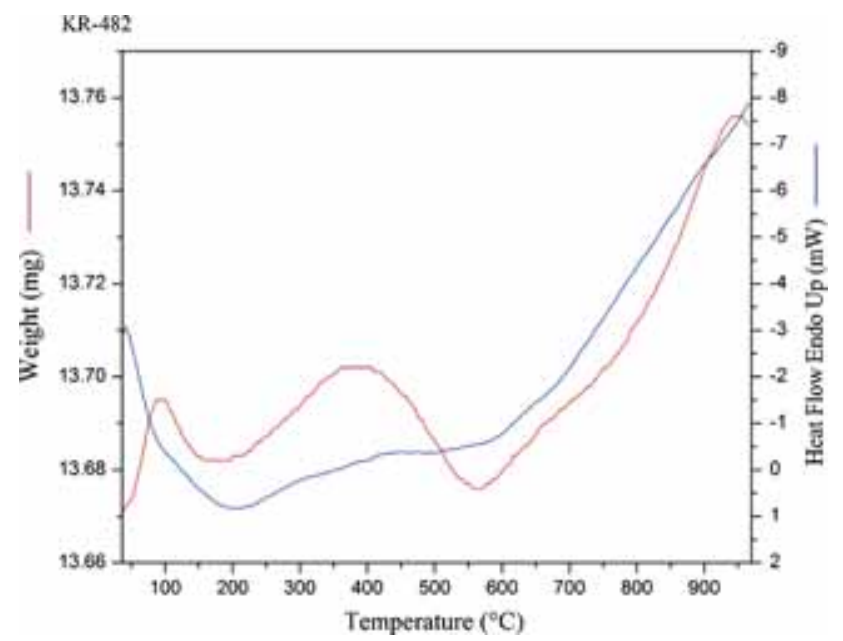

Figure 5. Thermal analysis chalcedony with DTA (blue) and TGA (red) curves.

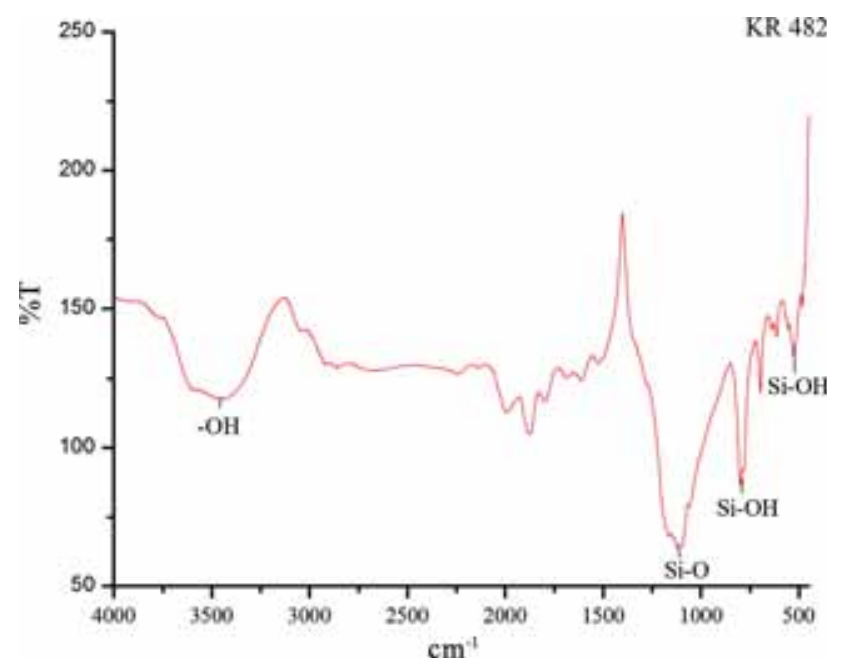

Figure 6. FTIR reflectance data of the secondary silica. Significant peaks are marked on the diagram. aliphatic stretch, whereas the broad peak at wavelength $3453 \mathrm{~cm}^{-1}$ confirms the presence of the $\mathrm{OH}$ bond. The Si-O out-of-plane vibration is conrmed from the peak at $458 \mathrm{~cm}^{-1}$ and the peak at $800 \mathrm{~cm}^{-1}$ confirms the Si-OH stretch (Pavia et al. 2001).

\section{Discussion and conclusions}

\subsection{Nomenclature and characterisation}

Quartz $\left(\mathrm{SiO}_{2}\right)$ has been traditionally classified into three general varieties, namely, macrocrystalline (varieties that develop visible crystals or are made of large intergrown crystals; macro-large), microcrystalline (compact varieties made of tiny crystal grains that are visible in an optical microscope; microsmall) and cryptocrystalline (dense varieties whose structure cannot be resolved using an optical microscope; crypto-hidden). The macrocrystalline varieties of silica are comprehensively called as 'quartz', whereas cryptocrystalline varieties are subsumed under the term 'chalcedony'. Low but variable refractive indices, fibrous appearance and undulose extinction are certain distinguishing optical properties of chalcedony (White and Corwin 1961). Varieties of macrocrystalline quartz include: rock crystal, amethyst, ametrine, aventurine, blue quartz, citrine, eisenkiesel, milky quartz, pink quartz, prase, prasiolite, rose quartz, smoky quartz, tiger's, hawk's, and cat's eye. Crypto- and microcrystalline quartz occur in two optically distinguishable varieties, namely, (i) fibrous chalcedony (agate, carnelian, chalcedony, chrysophase, onyx and sard and (ii) grainy chalcedony (chert, flint, heliotrope and plasma). The above distinction between fibrous and grainy varieties is based on the visual appearance of a thin section under a polarising microscope. Based on the conspicuous behaviour of chalcedony in polarised light, at least two types can be distinguished in thin sections (Michel-Lévy and Munier-Chalmas 1892; Correns and Nagelschmidt 1933; Braitsch 1957; Frondel 1978; Flörke et al. 1991), viz., length-fast chalcedony with crystallites stacks perpendicular to the $c$-axis wherein the fibres may be twisted around the elongation axis (Miech et al. 1984) and length-slow chalcedony or quartzine with crystallites stacked parallel to the $c$-axis (Flok and Pittman 1971). Recent studies based on SEM, transmission electron microscopy, selected area electron diffraction, etc. have demonstrated that both fibrous and grainy varieties of quartz consist of 
microscopically small intergrown crystal grains (Monroe 1964; Frondel 1978; Graetsch 1994; Cady et al. 1998; Lynne et al. 2007; quartzpage.de.html).

It is, however, generally agreed that the macrocrystalline quartz grows by adding molecules layer by layer, whereas cryprocrystalline chalcedony forms a colloidal watery solution of silica (Akhavan 2012), although some varieties such as chert, sinter, flint, jasper, etc., do not strictly fit into the above definition. Similarly, we were unable to distinguish our sample fitting into the above nomenclature, therefore, preferred to use a general term, chalcedony.

\subsection{Secondary silicates mineralisation in the basalts of the Deccan traps}

During the Cretaceous and the Tertiary periods, large parts of the present subcontinent of India were flooded by multiple lava flows. Seismological investigations have shown that the total remaining thickness in the north-east of the volcanic province is now about $100 \mathrm{~m}$ and at the elevations along the west coast up to $1500 \mathrm{~m}$. The lavas rose up through several fissures of the Earth's crust and flowed over large areas. As the lava cooled, many small, but also some large up to $100 \mathrm{~cm}$ across gas blisters and vesicles were preserved. At a later, post-volcanic time, these cavities were in-filled with calcium-rich silicates as well as with quartz and calcite that precipitated from hot aqueous solutions passing through the basalts. The chemical nature of these hydrothermal solutions was determined by the composition of the basalt, the length of contact with the basalt and the temperature (Deshmukh and Nair 1996).

The basalts of the Deccan traps have high calcium content, low magnesium and aluminium content, and an average $\mathrm{SiO}_{2}$ content of about $50 \%$. As the temperature of these solutions fell below $300^{\circ} \mathrm{C}$, clay minerals and chlorite get crystallised (Gottardi and Galli 1985). With the temperature sinking to $200-100^{\circ} \mathrm{C}$, prehnite, natrolite and laumontite followed. At temperatures of $110-90^{\circ} \mathrm{C}$, heulandite, stilbite and apophyllite developed, and at $90-60^{\circ} \mathrm{C}$, mesolite and scolecite formed. Finally, the low-temperature zeolites, thomsonite and chabazite crystallised (Ottens 2003).

Earlier workers have studied the zeolites from Deccan LIP. A systematic study of the secondary silicates provided possible zonation of zeolites within the lava flows (Sukheswala et al. 1974).
However, a subsequent study from the Western Ghats (Jeffery et al. 1988) has rejected the hypothesis of zeolite zonation. Although zeolite is one of the most commonly occurring secondary silicate along with quartz and chalcedony within the Deccan LIP, it occurs in relatively minor quantity within lava flows of the eastern Deccan traps. It is, however, understood that the secondary minerals in the Deccan traps were precipitated from fluids that migrated through the basalts, and there is evidence that most of the zeolites were formed at temperatures below $150^{\circ} \mathrm{C}$ (Jeffery et al. 1988; James and Walsh 1999). It is also assumed that the fluid was meteoric ground water rather than hydrothermal in origin, and that the dissolved materials in the fluids must have come from fluid-rock interaction (Parthasarathy 2006).

It had been demonstrated earlier that chalcedony and quartz were formed rapidly at $400^{\circ} \mathrm{C}$ (White and Corwin 1961); however, chalcedony gets converted to fibrous quartz and cannot persist any further. It was postulated that such transformations should take place at temperatures as low as $300^{\circ} \mathrm{C}$ (Kennedy 1950; Carr and Fyfe 1958; White and Corwin 1961) and complete conversion of amorphous silica to quartz was observed at $\sim 250^{\circ} \mathrm{C}$. Therefore, the upper limit for the formation of chalcedony was suggested to be $300^{\circ} \mathrm{C}$. On the other hand, mineral opal is present at lower temperatures below $100^{\circ} \mathrm{C}$, whereas quartz could not form below $100^{\circ} \mathrm{C}$. White (1955) noted that opal is replaced by chalcedony and quartz in hot spring deposits at temperatures greater than $100^{\circ} \mathrm{C}$. However, White et al. (1956) noted that opal could form at higher temperatures such as $\sim 140^{\circ} \mathrm{C}$, but it is unstable and changes to chalcedony and quartz, suggesting that the lower temperature limit of chalcedony is above $100^{\circ} \mathrm{C}$. Thus, the order of formation and persistence of chalcedony is within a range of $100-300^{\circ} \mathrm{C}$. Therefore, we assume that the deposition of chalcedony of the Deccan trap basalts should be within this temperature range.

Water-rich solutions are necessary for the formation of chalcedony. The nature of these solutions is of critical importance in determining whether chalcedony and quartz will form in a given time interval, or whether amorphous silica or crystoballite will persist. The hydrogen ion concentration $(\mathrm{pH})$ is an important factor in this regard. Opal is considered to be a disorderd low crystobalite. The sequence of changes of the various hydrous 
silica polymorphs shown is: amorphous silica (or opal) $\rightarrow$ crystoballite $\rightarrow$ chalcedony (or microcrystalline quartz). Similarly, it was noted by Braitsch (1957) that crystoballite gets converted to chalcedony, and that the 'silica gel' may change to crystobalite-opal or directly to chalcedony; or in some instances crystoballite-opal changes to chalcedony. Therefore, in conclusion, most chalcedony and chert are secondary products and require the former presence of gelatinous silica (Krauskorf 1956, 1959; White and Corwin 1961). During the present study, it was observed that the dominant cavity-filling minerals are quartz and chalcedony, which indicates a temperature range of $\sim 100-300^{\circ}$. The relative absence of opal and crystoballite in the cavities (amygdules) probably indicate that the mother fluid was a hot aqueous solution that crystallised as chalcedony and crystalline secondary quartz within the Deccan traps of Nagpur city.

\subsection{Genesis of hydrous amorphous silica}

Hydrous amorphous silica is a common product of incongruent chemical weathering of basalt glass and basalt-associated minerals; therefore silica coatings are frequently observed in other basaltic terrains (Gordon and Dorn 2005; Fulignati et al. 2006; Prinsloo et al. 2010). Silica coatings are also frequently observed in arid deserts (Weed and Ackert 1986; Perry et al. 2006) as well as anthropogenically altered terrains (Schindler et al. 2009; Durocher and Schindler 2011; Mantha et al. 2012). These were suggested to occur even on the surface of Mars (Kraft et al. 2003; Skok et al. 2010).

Various mechanisms have been proposed for the formation of silica coatings and cements e.g., Hawaiian flows, such as:

(1) dissolution-reprecipitation of near surface glasses (Minitti et al. 2007; Hellmann et al. 2013);

(2) dissolution-reprecipitation of windblown particulates (Farr and Adams 1984; Curtiss et al. 1985); and

(3) transport and deposition of externally derived Si in solution (Schiffman et al. 2006).

However, the timing and the rate of coating of the formation are poorly understood. The dissolution rates of basaltic glass have been studied experimentally by many researchers (Oelkers and Gislason 2001; Gislason and Oelkers 2003; Tosca et al. 2004; Wolff-Boenisch et al. 2004; Hurowitz et al. 2005; Gudbrandsson et al. 2011). However, in-situ weathering rates may be orders of magnitude lower than those measured experimentally (White and Brantley 2003).

It has been demonstrated earlier that the silicarich coatings may form on basalt over long time periods under neutral pH conditions (Dorn 2012); however, recent studies show that such coatings might be formed by the interaction with acidic fluids and vapours (Chemtomb and Rossman 2014). For instance, the high sulphur content of Kilauean silica coatings, primarily present as jarosite (Minitti et al. 2007; Chemtob et al. 2010) indicated that $\mathrm{SO}_{2}$ was the primary volcanically derived acid source involved in coating formation. The analogy is equally applicable to the Deccan trap basalts, in which, the following were proposed to be the sources of acids and sulphur: volcanically derived acids, including local fissure vents, regional plumes and volatiles degassed from the lava itself. The presence of sulphur within the Deccan magma has been amply demonstrated, e.g., Randive et al. (2015). More detailed sampling covering a larger area might help in understanding the nature of mother fluid which crystallised secondary silica all over the Deccan plateau.

\section{Acknowledgements}

We thank the Head of the Department of Geology, RTM Nagpur University for providing the necessary permission to carry out this work and to use the facilities. We thank Sanjeevani Jawadand, Shubhangi Lanjewar and Sarang Muley for drafting the figures. KRR thanks Chetana and Raghav for their kind cooperation.

\section{References}

Akhavan A C 2012 Types of quartz, chapter's topic; The quartz page, http://www.quartzpage.de/gen_types.html.

Apte A S and Phadke A V 1996 Rehydration capacity of the industrially significant natural zeolites and associated phyllosilicates occurring as cavity minerals in the basaltic lava flows of the western Deccan volcanic province; Gondwana Geol. Mag. Spec. 2 501-510.

Avasia R K and Gangopadhyay M 1984 Distribution of secondary minerals in the Western Deccan Traps of Bombay-Baroda tract, India; Indian Miner. Sukheswala, pp. $215-230$. 
Barth T F W 1952 Theoretical petrology; Wiley, New York, $416 \mathrm{p}$.

Braitsch O 1957 On the natural fiber and aggregation type of $\mathrm{SiO}_{2}$, their form of adhesion, directional statistics and birefringence, Heidelberg; Contrib. Mineral. Petrol. 5 331-372 (in German).

Cady S L, Wenk H R and Sintubin M 1998 Microfibrous quartz varieties: Characterization by quantitative X-ray texture analysis and transmission electron microscopy; Contrib. Mineral. Petrol. 130 320-335.

Carr R M and Fyfe W S 1958 Some observations on the crystallization of amorphous silica; Am. Mineral. 43 908-916.

Chemtomb S M and Rossman G R 2014 Timescales and mechanisms of formation of amorphous silica coatings on fresh basalts at Klauea Volcano, Hawai'i; J. Volcanol. Geotherm. Res. 286 41-54.

Chemtob S M, Jolliff B L, Rossman G R, Eiler J M and Arvidson R E 2010 Silica coatings in the Ka'u Desert, Hawaii, a Mars analog terrain: A micromorphological, spectral, chemical, and isotopic study; J. Geophys. Res. Planets 115 1-19.

Correns C W and Nagelschmidt G 1933 About faserbau and optical properties from chalcedony; J. Crystallogr. 85 199-213.

Curtiss B, Adams J B and Ghiorso M S 1985 Origin, development and chemistry of silica-alumina rock coatings from the semi-arid regions of the Island of Hawaii; Geochim. Cosmochim. Acta 49(1) 49-56.

Deshmukh S S and Nair K K K 1996 Deccan basalts; Gondwana Geol. Mag. Spec. 2 538p.

Deshpande G G 1998 Geology of Maharashtra, Geological Society of India, Bangalore, 223p.

Dorn R I 2012 Formation of silica glaze rock coatings through water vapor interactions; Phys. Geogr. 33(1) 21-31.

Durocher J L and Schindler M 2011 Iron-hydroxide, ironsulfate and hydrous-silica coatings in acid-mine tailings facilities: A comparative study of their trace-element composition; Appl. Geochem. 26(8) 1337-1352.

Farr T G and Adams J B 1984 Rock coatings in Hawaii; Geol. Soc. Am. Bull. 95(9) 1077-1083.

Flok R L and Pittman J S 1971 Length-slow chalcedony: A new testament for vanished evaporites; J. Sedim. Res. 41 $1045-1058$.

Flörke O W, Graetsch H, Martin B, Röller K and Wirth R 1991 Nomenclature of micro- and non-crystalline silica minerals based on structure and microstructure; New Yearbook Mineral.-Pap. 163 19-42.

Frondel C 1978 Characters of quartz fibers; Am. Mineral. 63 $17-27$.

Fulignati P, Sbrana A, Clocchiatti R and Luperini W 2006 Environmental impact of the acid fumarolic plume of a passively degassing volcano (Vulcano Island, Italy); Environ. Geol. 49(8) 1139-1155.

Gislason S R and Oelkers E H 2003 Mechanism, rates, and consequences of basaltic glass dissolution: II. An experimental study of the dissolution rates of basaltic glass as a function of $\mathrm{pH}$ and temperature; Geochim. Cosmochim. Acta 67(20) 3817-3832.

Gordon S J and Dorn R I 2005 Localized weathering: Implications for theoretical and applied studies; Prof. Geogr. 57(1) 28-43.
Gottardi G and Galli E 1985 Natural zeolites; Springer-Verlag, New York.

Graetsch H 1994 Structural characteristics of opaline and microcrystalline silica minerals; In: Reviews in mineralogy, Vol. 29, Silica - Physical behavior, geochemistry and materials applications, Mineralogical Society of America, Washington, DC.

Gudbrandsson S, Wolff-Boenisch D, Gislason S R and Oelkers E H 2011 An experimental study of crystalline basalt dissolution from $2 \leq \mathrm{pH} \leq 11$ and temperatures from 5 to 75 degrees C; Geochim. Cosmochim. Acta 75(19) 5496-5509.

Gwalani L G and Dalal V P 1988 Environmental geologic study of Nagpur city (Maharashtra, India) and its vicinity; In: The COMPASS: The earth-science journal of sigma (ed.) Merriam D F, Gamma, Epsilon, USA, Vol. 65, No. 2, pp. $124-132$.

Hatipoglu M, Tuncer Y, Kibar R, Cetin A and Can N 2010 Thermal properties of gem-quality moganite-rich blue chalcedony; Physica B 405 4627-4633.

Hellmann R, Daval D and Wirth R 2013 Formation of amorphous silica surface layers by dissolution-reprecipitation during chemical weathering: Implications for $\mathrm{CO}_{2}$ uptake; Proc. Earth Planet. Sci. 7 346-349.

Hislop S and Hunter R 1855 On the fossils and the neighbourhood of the Nagpur, central India; Quart. J. Geol. Soc. 11(1-2) 345-383.

Hurowitz J A, McLennan S M, Lindsley D H and Schoonen M A A 2005 Experimental epithermal alteration of synthetic Los Angeles meteorite: Implications for the origin of Martian soils and identification of hydrothermal sites on Mars; J. Geophys. Res. Planets 110(E7) 1-22.

James S and Walsh J N 1999 Zeolites from the Deccan basalts: Chemistry and formation; In: Deccan volcanic province (ed.) Subbarao K V, Geol. Soc. India Memoir 43(2) 803-817.

Jeffery K L, Henderson P, Subbarao K V and Walsh J N 1988 The zeolites of the Deccan basalts - A study of their distribution; Geol. Soc. India Memoir 10 151-162.

Kennedy G C 1950 A portion of the system silica water; Econ. Geol. 45 629-653.

Kraft M D, Michalski J R and Sharp T G 2003 Effects of pure silica coatings on thermal emission spectra of basaltic rocks: Considerations for Martian surface mineralogy; Geophys. Res. Lett. $\mathbf{3 0}(\mathbf{2 4})$ 2288, https://doi.org/10. 1029/2003gl018848.

Krauskorf K B 1956 Dissolution and precipitation of silica at low temperatures; Geochim. Cosmochim. Acta 10 1-26.

Krauskorf K B 1959 The geochemistry of silica in sedimentary environments. Silica in sediments, society of economic paleontologists and mineralogists; Am. Assoc. Petrol. Geol. SP7 4-19.

Lynne B Y, Campbell K A, James B J, Browne P R L and Moore J 2007 Tracking crystallinity in siliceous hot spring deposits; Am. J. Sci. $307612-641$.

Mantha N M, Schindler M, Murayama M and Hochella M F 2012 Silica- and sulfate bearing rock coatings in smelter areas: Products of chemical weathering and atmospheric pollution I. Formation and mineralogical composition; Geochim. Cosmochim. Acta 85 254-274.

Michel-Lévy A and Munier-Chalmas C P E 1892 Memories on various forms affected by the elementary network of quartz; Bull. Mineral. Soc. France 15 159-190. 
Miech G, Graetsch H and Florke O W 1984 Crystal structure and growth fibers of length-fast chalcedony; Phys. Chem. Minerals 10 197-199.

Minitti M E, Weitz C M, Lane M D and Bishop J L 2007 Morphology, chemistry, and spectral properties of Hawaiian rock coatings and implications for Mars; J. Geophys. Res. Planets 112(E5) 1-24.

Mohabey D M and Udhoji S G 1996 Fauna and flora from Late Cretaceous (Maestrichtian) non-marine lameta sediments associated with Deccan Volcanic episode, Maharashtra: Its relevance to the $\mathrm{K}-\mathrm{T}$ boundary problem, paleoenvironment and palaeogeography; In: Deccan basalts (eds) Deshmukh S S and Nair K K K, Gondwana Geol. Soc. Spec. 2 349-364.

Monroe E A 1964 Electron optical observations of fine-grained silica minerals; Am. Mineral. 49 339-347.

Oelkers E H and Gislason S R 2001 The mechanism, rates and consequences of basaltic glass dissolution: I. An experimental study of the dissolution rates of basaltic glass as a function of aqueous $\mathrm{Al}, \mathrm{Si}$ and oxalic acid concentration at 25 degrees $\mathrm{C}$ and $\mathrm{pH}=3$ and 11; Geochim. Cosmochim. Acta 65(21) 3671-3681.

Ottens B 2003 Calcite from the Deccan: Traps of India; Rocks Miner. 80(2) 94-107, https://doi.org/10.3200/rmin.80.2. 94-107.

Pande P C, Suryanarayana K and Deshpande G G 1969 Geology and ground water resources of Nagpur city and its surrounding area in Maharashtra; Miner. Res. 1(2) 22-25.

Parali L, Sabikoglu I, Tucek J, Pechousek J, Novak P and Navarik J 2015 Dielectric behaviors at microwave frequencies and Mossbauer effects of chalcedony, agate, and zultanite; Chin. Phys. B 24(5) 059101.

Parthasarathy G 2006 Zeolite zonation and amygdaloidal minerals from the Killari borehole of Deccan traps, Maharashtra, India; Appl. Geochem. 4 546-557.

Patil R R, Panchapakeshan V and Sahu R N 1981 Fluid inclusion studies on amygdaloidal and vein calcite in Deccan Traps; In: Deccan volcanism and related basalt provinces in other parts of the world (eds) Subbbarao K V and Sukheswala R N, Geol. Soc. India Memoir 3 422-427.

Pavia D L, Lampman G M and Kriz G S 2001 Introduction to spectroscopy; Department of Chemistry, Western Washington University, Bellingham, Washington, 15p.

Pelto C R 1956 A study of chalcedony; Am. J. Sci. 254 32-50.

Perry R S, Lynne B Y, Sephton M A, Kolb V M, Perry C C and Staley J T 2006 Baking black opal in the desert sun: The importance of silica in desert varnish; Geology 34(7) 537-540.

Pettijohn F J 1957 Sedimentary rocks (2nd edn); Harper and Brothers, New York, 628p.

Phadke A V and Bapat L 1984 Gamma sensitized luminescence studies from geodes in basalts near Chinchwad, Pune district, Maharashtra; In: Proceedings of symposium on Deccan trap and bauxite; Geological Survey of India Special Publication No. 14, pp. 86-88.

Pittman J S Jr 1959 Silica in Edwards limestone, Travis County, Texas; In: Silica in Sediments (ed.) Ireland H A, Soc. Econ. Paleontologists Mineralogists, Spec. Publ. No. 7 , pp. 121-134.
Prinsloo L C, Colomban P, Brink J D and Meiklejohn I 2010 A Raman spectroscopic study of the igneous rocks on Marion Island: A possible terrestrial analogue for the geology on Mars; J. Raman Spectrosc. 42(4) 626-632.

Rakovan J 2005 Amygdule. World to the wise; Rocks Minerals 80 202-203.

Randive K R, Vijaya Kumar J and Korakoppa M 2015 PGE mineralization in the cumulate gabbro of Phenai Mata Complex, Deccan Large Igneous Province, India; Curr. Sci. India 108(10) 1796-1798.

Schiffman P, Zierenberg R, Marks N, Bishop J L and Dyar M D 2006 Acid-fog deposition at Kilauea volcano: A possible mechanism for the formation of siliceous sulfate rock coatings on Mars; Geology 34(11) 921-924.

Schindler M, Durocher J L, Abdu Y and Hawthorne F C 2009 Hydrous silica coatings: Occurrence, speciation of metals, and environmental significance; Environ. Sci. Technol. $43(23)$ 8775-8780.

Skok J R, Mustard J F, Ehlmann B L, Milliken R E and Murchie S L 2010 Silica deposits in the Nili Patera caldera on the Syrtis Major volcanic complex on Mars; Nat. Geosci. 3 838-841, https://doi.org/10.1038/ngeo990.

Subramanyanan P R, Parveen S, Shastry B V and Gwalani L G 1996 Hydrological features of Nagpur city in the Vidarbha region of Maharashtra; In: Mineral and groundwater resources of Vidarbha, symposium (eds) Mohabey $\mathrm{N}$ K, Gwalani L G and Mohabey D M, pp. 235-242.

Sukheswala R N and Poldervaart A 1958 Deccan basalts of Bombay area, India; Bull. Geol. Soc. Am. 69 1475-1494.

Sukheswala R N, Avasia R K and Gangopadhyay M 1974 Zeolites and associated secondary minerals in the Deccan Traps of Western India; Mineral. Mag. 39 658-671.

Tosca N J, McLennan S M, Lindsley D H and Schoonen M A A 2004 Acid-sulfate weathering of synthetic Martian basalt: The acid fog model revisited; J. Geophys. Res. Planets 109(E5) 1-29.

Weed R and Ackert R P 1986 Chemical-weathering of Beacon supergroup sandstones and implications for Antarctic glacial chronology; S. Afr. J. Sci. 82(9) 513-516.

White A F and Brantley S L 2003 The effect of time on the weathering of silicate minerals: Why do weathering rates differ in the laboratory and field? Chem. Geol. 202(3-4) 479-506.

White D E 1955 Thermal springs and epithermal ore deposits; In: Economic geology (ed.) Bateman A M, Fiftieth Anniversary, Vol. 1905-1955, Part I, pp. 99-154.

White D E, Brannock W W and Murata K J 1956 Silica in hotspring waters; Geochim. Cosmochim. Acta 10 27-59.

White J F and Corwin J F 1961 Synthesis and origin of chalcedony; Am. Mineral. 46 112-119.

Williams H, Turner F J and Gilbert C M 1954 Petrography; Freeman and Company, San Francisco, 406p.

Wolff-Boenisch D, Gislason S R, Oelkers E H and Putnis C V 2004 The dissolution rates of natural glasses as a function of their composition at $\mathrm{pH} 4$ and 10.6, and temperatures from 25 to 74 degrees C; Geochim. Cosmochim. Acta $\mathbf{6 8}(\mathbf{2 3})$ 4843-4858. 